This work is licensed under a Creative Commons Attribution 4.0 International License.

\title{
USPOREDBA BRZINE GOVORA U MATERINSKOME HRVATSKOME (L1) I STRANOME ENGLESKOME (L2) JEZIKU
}

dr. sc. Mirjana Matea Kovač, Filozofski fakultet, mirjana@ffst.hr, Split

izvorni znanstveni članak

UDK 81'232

$81^{\prime} 242$

$81 ' 243$

rukopis primljen: 29. 10. 2017.; prihvaćen za tisak: 29. 3. 2018.

Cilj je ovog istraživanja uspoređivanje brzine govora između hrvatskoga (J1) i engleskoga (J2) jezika. Odabrani zadatci uključuju opise dinamičnih konstelacija u kojima je potrebno planirati $i$ kronološki organizirati govorne činove $u$ stvarnom vremenu te opise prostorno-statičkih konstelacija i njihovih međusobnih odnosa. Ispitanici su govorne zadatke najprije izvršili na materinskome, a potom na stranome jeziku. Pretpostavilo se da bi zbog neautomatizirane uporabe stranoga jezika govornici trebali znatno sporije govoriti na stranome jeziku u svakom zadatku. Dobiveni rezultati upućuju na to da je brzina govora značajno sporija kod naracije duljeg trajanja u J2 zbog konceptualne složenosti zadatka. S druge strane, nisu zabilježene statistički značajne razlike u brzini govora između uspoređivanih jezika kod vrlo strukturiranih zadataka kraćeg trajanja $i$ ponovljenih zadataka. Budući da su zadatci već napravljeni na materinskome jeziku, umanjuju se zahtjevi za procesiranjem govora na razini konceptualizacije te govorniku više vremena i pažnje preostaje za fazu formulacije i artikulacije u J2. Također, nepostojanje značajnih razlika može se objasniti postojanjem jakih asocijativnih veza između J1 i J2 te pojavljivanjem iznimno učestalih riječi koje se brže prizivaju iz mentalnog leksikona, posebice ako su prethodno prizvane na materinskome jeziku. Uvođenje novih tema veći je kognitivni napor u fazi konceptualizacije, što rezultira osjetno sporijom brzinom govora u materinskome i u stranome jeziku.

Ključne riječi: brzina govora; proizvodnja govora; fluentnost; mentalni leksikon 


\section{Uvod}

Brzina govora smatra se jednim od najboljih parametara za procjenu govornikove fluentnosti u stranome jeziku. Cucchiarini i sur. (2002) iznose da ocjene stručnjaka, koje se odnose na njihov doživljaj ispitanikove fluentnosti, najjače koreliraju s brzinom govora. Ostali parametri kao što su brzina artikulacije, omjer vremena fonacije i vremena govorenja, broj stanki te trajanje stanki rezultiraju nižim vrijednostima koeficijenata korelacije. Oni zaključuju da je samo u slučaju kognitivno zahtjevnijih zadataka najbolji pretkazatelj percipirane fluentnosti srednja duljina izričaja, odnosno broj slogova između dviju stanki. Naglašavaju da je brzina govora iznimno važan parametar zato što povezuje obje komponente, brzinu artikulacije glasova i govornikove stanke, a one negativno utječu na percepciju govornikove fluentnosti. U njihovu istraživanju brzina govora znatno je korelirala s ocjenama fluentnosti izvornih govornika u zadatcima čitanja i u spontanom govoru. Kormos i Dénes (2004) također smatraju da je brzina govora dobar pretkazatelj percipirane fluentnosti iako iznose da je srednja duljina izričaja bolji pretkazatelj percipirane fluentnosti. Ullakonoja (2009) naglašava da je brzina govora bolji indikator fluentnosti od brzine artikulacije u govoru stranoga jezika jer se potonja dobiva kao kvocijent broja riječi ili slogova i vremena govorenja, ali bez stanki između izričaja, koje znatno utječu na doživljaj govornikove fluentnosti. Brzina govora dobar je indikator ukupne govornikove izvedbe, odnosno, što je manje stanki i što je dulje trajanje govornih odsječaka, govornik proizvodi više riječi u minuti (Götz 2013).

Jedinice u kojima se mjeri brzina govora u dosadašnjoj literaturi variraju od broja riječi u minuti, broja riječi u sekundi, broja slogova u minuti, slogova u sekundi ili broja fonema po jedinici vremena. Pri tome se pri izračunavanju ukupna broja riječi/slogova u obzir mogu uzimati sve izgovorene riječi ili se mogu odbiti različiti oblici disfluentnoga govora (nefonemski odsječci, samoispravljanja, ponavljanja i sl.). Škarić (1991) navodi da najveća govorna brzina iznosi 13-14 slogova u sekundi, a iznad te brzine govor se dezintegrira i postaje neprepoznatljiv. Automatizirana uporaba materinskog jezika omogućuje veliku brzinu govora od dvije do tri riječi, pet do šest slogova ili 15 do 18 fonema u sekundi u prirodnome razgovornom govoru (Horga i Mukić 2000). Horga (1988) je za hrvatski jezik dobio da je tempo govora 5,2 sloga u sekundi za čitani tekst i 6,9 za brzo čitani tekst. 
Horga i Mukić (2000) promatraju vremenske parametre stanki i govornih članaka u TV dnevnicima HRT-a, i to za četiri govorne uloge koje se pojavljuju u TV dnevnicima: za voditelje, spikere, reportere i neprofesionalne govornike. Zaključuju da muški profesionalni televizijski govornici imaju brži tempo artikulacije i tempo govora nego ženski, dok su u spontanom govoru neprofesionalnih govornika žene brže od muškaraca, i to osobito u tempu govora jer upotrebljavaju znatno manje stanki. Zaključuju da profesionalni govornici imaju iskustvo javnog nastupa te je njihov govor brži, a izričaj složeniji.

Horga i Požgaj Hadži (2012) istražuju razlikuje li se fluentnost govora u javnim i komercijalnim medijima s obzirom na činjenicu da su različita stupnja formalnosti, odnosno spontanosti. Potvrđeno je da postoje znatne razlike između govora $u$ dvama promatranim radijskim programima te se pretpostavlja da su one prouzročene različitim zahtjevima za formalnošću govora.

Brzina govora u materinskome jeziku iznosi između 120 i 260 riječi u minuti (Marslen-Wilson 1973; Pimsleur i sur. 1977; Rivers 1981; Richards 1983). Velika razlika između navedene donje i gornje granice posljedica je činjenice da različite komunikacijske situacije rezultiraju različitim brzinama govora, kao i činjenice da postoje velike oscilacije u govornim stilovima izvornih govornika.

Brzina govora u stranome jeziku opada u odnosu na brzinu govora u materinskome jeziku zbog ograničenja u govornom procesiranju, dekodiranju i prizivanju fonološke informacije ili poteškoća u artikulaciji, odnosno zbog kombinacije navedenih razloga (Munro i Derwing 1995; 2001). Niža brzina govora često se navodi kao jedna od zapreka razumljivosti i sadržajnosti govornog izričaja (Munro i Derwing 1998; 2001), kao oznaka neizvornosti govornika (Anderson-Hsieh i Koehler 1988) te kao izvor stereotipa prema govornicima stranoga jezika (Zuengler 1988).

Požgaj Hadži i sur. (2012) ispituju odnos stupnja vladanja jezikom i govorne fluentnosti uspoređujući ispitanike kojima je materinski jezik slovenski (L1), a hrvatski strani jezik (L2). Nalaze da govornici u slovenskom jeziku izgovaraju manje slogova u sekundi u odnosu na hrvatski jezik, ali razlike nisu statistički značajne. Međutim, brzina govora u L2 uvjetovana je kognitivnom složenošću govornoga diskursa, odnosno složeniji diskurs rezultira sporijom brzinom govora. Dobiveni rezultati koji su uključivali trajanje i učestalost stanki, prosječnu srednju duljinu izričaja, 
brzinu govora i brzinu artikulacije upućuju na to da je govorna fluentnost ponajprije uvjetovana razinom vladanja jezikom, ali i kognitivnim sposobnostima.

Trofimovich i Baker (2006) uspoređuju brzinu govora deset izvornih govornika engleskoga jezika s tri skupine od po deset govornika stranoga jezika čija je duljina neprekidna boravka u engleskome govornom području tri mjeseca, tri godine i deset godina. Brzina govora dobivena je na temelju zadatka u kojem su ispitanici trebali ponoviti zadane rečenice. Ispitana skupina s boravkom od tri mjeseca govorila je oko $23 \%$ sporije od izvornih govornika, dok se za ostale dvije skupine razlika smanjila na nešto više od $18 \%$.

Hincks (2005) uspoređuje brzinu govora pet studenata koji slušaju kolegij Tehnički engleski, izvornih govornika švedskoga jezika pri prezentiranju sadržaja na engleskome i materinskome jeziku. Zaključuje da govornici u švedskome jeziku govore $20 \%$ brže u odnosu na govor na engleskome jeziku. Autorica postavlja pitanje uspijevaju li govornici u engleskome jeziku u trajanju dodijeljenog vremena za prezentaciju iznijeti samo dio onoga sadržaja koji iznesu u švedskome jeziku. Hincks (2010) objavljuje istraživanje u kojemu, osim ispitivanja brzine govora, istražuje i posljedice manje brzine govora na govornikovu sposobnost da prenese informaciju. U ovom istraživanju sudjeluje 14 studenata diplomskog studija inženjerstva, izvornih govornika švedskoga jezika, koji održavaju prezentacije na materinskome i engleskome jeziku. Autorica nalazi da je brzina govora $23 \%$ niža na engleskome jeziku te da je znatno smanjila informacijski sadržaj prezentacija na engleskome jeziku, pri čemu je vrijeme prezentiranja bilo jednako za oba jezika.

Airey (2010) analizira sposobnost 21 studenta preddiplomskih studija da usmeno opiše i obrazloži na materinskome i engleskome jeziku znanstvene koncepte koje je susreo na predavanjima. Nalazi da studenti imaju $45 \%$ nižu brzinu govora i $33 \%$ kraće srednje duljine izričaja u stranome jeziku. Te razlike postaju znatno niže (28 \% i $26 \%$ ) ako se u obzir uzmu samo studenti koji su ispravno shvatili koncepte koje su čuli na predavanjima. Razlika u brzini govora u potonjem se slučaju ne razlikuje puno od vrijednosti koje je dobila Hincks u svojim istraživanjima, kao i Trofimovich i Baker (2006) za skupinu koja je najkraće boravila u engleskome govornom području.

Za razliku od većine prethodnih radova u kojima su ispitanici bili studenti, Thogersen i Airey (2011) istražuju utjecaj promjene brzine govora 
u stranome jeziku na sadržaj predavanja nastavnika. Nalaze da predavaču treba $22 \%$ više vremena da izloži isti sadržaj u stranome jeziku u odnosu na materinski jezik. Također, predavač govori $23 \%$ sporije u stranome jeziku upotrebljavajući formalniji stil od retoričkoga stila kojim se koristi u materinskome jeziku. Doprinos je ovog rada i u tome što je ustanovljeno da se slične razlike u brzini govora između materinskoga i stranoga jezika ne odnose samo na studente nego i na iskusne predavače na stranome jeziku. Baese-Berk i Morrill (2015) pokazuju da nije samo srednja brzina govora niža nego su i promjene brzine govora od izričaja do izričaja naglašenije u govornika stranoga jezika.

U ovome radu uspoređuje se brzina govora u materinskome (hrvatskom) i stranome (engleskom) jeziku za različite tipove govornih zadataka radi daljnje kvantifikacije odstupanja brzine govora u stranom jeziku u odnosu na materinski te dobivanja novih spoznaja o utjecaju tipa zadatka na razlike u brzini govora. Istraživanje je potaknuto činjenicom da autorica u pojedinim tipovima zadataka, istražujući govorne disfluentnosti, nije na kvalitativnoj razini osjetila promjenu u brzini govora ispitanika na materinskome i stranome jeziku. Treba naglasiti da je ispitivanje provedeno na uzorku od 101 sudionika čije je trajanje govora u materinskome (hrvatskom) jeziku bilo gotovo osam sati, a u stranome (engleskom) jeziku gotovo deset sati te je $s$ takvim brojčanim iznosima najopsežnije istraživanje u usporedbi $s$ prethodno navedenim analizama brzine govora u dosadašnjoj literaturi.

\section{Cilj istraživanja i metodološki postupci}

U ovome istraživanju sudjelovao je 101 student na Fakultetu elektrotehnike, strojarstva i brodogradnje u Splitu. Ispitanici su studenti prve godine elektrotehnike i informacijske tehnologije te slušaju kolegij Engleski jezik kao jezik struke radi svladavanja osnovne stručne terminologije i gramatičkih struktura specifičnih za tehnički engleski jezik. Očekivana komunikacijska kompetencija ispitanika u engleskom jeziku nakon obveznog učenja engleskog jezika u osnovnoj i srednjoj školi u skladu sa Zajedničkim europskim referentnim okvirom za jezike (CEFRL) procjenjuje se kao B1 ili B2. Pretpostavlja se da su ispitanici na razini govorne interakcije sposobni povezivati rečenice da bi opisali doživljaje i događaje, da mogu ukratko obrazložiti i objasniti svoja stajališta i planove te ispričati priču ili prepričati sadržaj knjige ili filma te opisati svoje reakcije. Ispitanici su se dobrovoljno javili za potrebe istraživanja, a prije samog testiranja nije proveden test 
provjere stupnja poznavanja engleskoga jezika. Istraživanje je provedeno u vrlo neformalnom okruženju da bi se smanjila napetost govornika. Ispitanici su sjedili nasuprot istraživaču u kabinetu na Fakultetu, a svaki je ispitanik individualno snimljen, nakon čega su svi zvučni zapisi transkribirani i provjerio ih je još jedan istraživač da bi se dodatno potvrdila vjerodostojnost skupljenih materijala. Neposredno prije početka samog snimanja svaki ispitanik bio je upoznat s prirodom zadatka te je dobio eksplicitne upute što pojedini zadatak zahtijeva. Analizom zvučnog zapisa zabilježena je brzina govora svakog studenta na materinskome i stranome jeziku. U ovom istraživanju brzine govora, kao ukupna broja riječi po minuti, ukupan je broj riječi dobiven brojenjem cjelovitih riječi, necjelovitih riječi, leksikaliziranih i neleksikaliziranih poštapalica te ponavljanja (Bortfeld i sur. 2001). Analizom zvučnog zapisa u programskom paketu Audacity izmjereno je vrijeme izgovora.

Odabrani zadatci uključuju opise dinamičnih konstelacija u kojima je potrebno planirati i oblikovati izričaje pod pritiskom vremena te opise prostorno-statičkih konstelacija i njihovih međusobnih odnosa. Prvi je zadatak (FILM) narativne prirode, a ispitanici su trebali prepričati sadržaj crtanoga filma koji su prethodno pogledali na engleskome jeziku u trajanju od pet minuta. Odabrani crtani film bio je relativno nepoznat ispitanicima, a sama izvedba zadatka bila je zahtjevna u smislu diskursne organizacije sadržaja priče. Nakon gledanja crtanoga filma ispitanik je trebao prepričati sadržaj na materinskome, a potom na stranome jeziku. Ispitanici nisu bili ograničeni vremenom. Drugi je zadatak (SOBA1) tražio vjeran opis rasporeda namještaja u sobi. U trećem zadatku (SOBA2) ispitanik je morao opisati razmještaj namještaja koji je bio drukčije raspoređen u odnosu na zadatak SOBA1. U četvrtome zadatku (IZORE) ispitanici su na temelju pet nepovezanih slikovnih prikaza trebali oblikovali sadržajno nepovezane izričaje. U svakom izričaju trebalo je navesti odgovarajuću boju i predmet sa slike, a sintaktički okvir nije bio unaprijed zadan. U petome zadatku (STRIP) ispitanici su trebali osmisliti i oblikovati kratku priču na temelju pet slikovnih prikaza, a nijedan slikovni prikaz nije smio biti izostavljen. U tome, kao i u ostalim zadatcima, ispitanici nisu bili ograničeni vremenom.

Postavljena je sljedeća hipoteza:

U materinskome jeziku bit će znatno veća brzina govora u svakom zadatku u odnosu na brzinu govora u odgovarajućim zadatcima na stranome jeziku. 
Zbog neautomatizirane uporabe stranoga jezika govornici bi trebali mnogo sporije govoriti na stranome jeziku, kao što je to bio slučaj u istraživanjima predstavljenima u dosadašnjoj literaturi.

Cilj je ovog istraživanja kvantifikacija odstupanja brzine govora u stranome jeziku u odnosu na materinski za svaki od prethodno opisanih zadataka da bi se dobile nove spoznaje o utjecaju tipa zadatka na razlike u brzini govora.

\section{Rezultati i rasprava}

Istraživanje utjecaja tipa zadatka na razliku u brzini govora između stranoga (engleskog) i materinskoga (hrvatskog) jezika provedeno je na istim ispitanicima u oba jezika na pet različitih zadataka opisanih u prethodnom poglavlju. Posljedično, riječ je o zavisnim ili uparenim uzorcima. Prije odabira odgovarajućega statističkog testa potrebno je provjeriti preduvjet uporabe parametrijskog testa (s obzirom na to da se uspoređuju dva uzorka na 101 ispitaniku, riječ je o t-testu za velike zavisne uzorke). Ako preduvjet normalnih distribucija nje ispunjen, bira se Wilcoxonov test za uparene uzorke kao odgovarajući neparametrijski test za dva zavisna uzorka.

U tablici 1 prikazane su pojedine uzoračke vrijednosti i izračunate veličine za brzinu govora u oba jezika u zadatku FILM. Može se primijetiti da je brzina govora u J2 za više od $22 \%$ niža u odnosu na J1, što je iznos koji se vrlo dobro slaže s rezultatima dobivenima u dosadašnjoj literaturi te predstavljenima u uvodu. Zbog veličine uzoraka $(n=101)$ standardna pogreška aritmetičke sredine ne prelazi 2,5 riječi po minuti, tablica 1 . Iako je iznos odstupanja dovoljno velik da se može zaključiti i bez provođenja odgovarajućega statističkog testa da postoji statistički značajna razlika u brzini govora, ipak je zbog konačne i neosporive potvrde i proveden.

Za testiranje normalnosti odabran je Shapiro-Wilkov test normalnosti, koji je u literaturi učestalo istaknut kao najefikasniji test normalnosti. 
Tablica 1: Uzoračke vrijednosti i parametri brzine govora za zadatak FILM

\begin{tabular}{|c|c|c|}
\hline FILM & Materinski jezik & Strani jezik \\
\hline $\boldsymbol{x}_{\min }$ & 81,457 & 59,062 \\
\hline $\boldsymbol{M} \boldsymbol{e}$ & 137,535 & 105,106 \\
\hline $\boldsymbol{x}_{\max }$ & 204,243 & 197,336 \\
\hline$\overline{\boldsymbol{x}}$ & $\mathbf{1 3 7 , 6 3 2}$ & $\mathbf{1 0 6 , 6 5 8}$ \\
\hline$\sigma^{2}$ & 579,365 & 629,107 \\
\hline$S_{\bar{x}}$ & 2,395 & 2,496 \\
\hline$\Delta \bar{x}$ & \multicolumn{2}{|c|}{$-\mathbf{2 2 , 5 4 9 \%}$} \\
\hline
\end{tabular}

$x_{\text {min }}$ - minimalna vrijednost, $M e$ - medijan, $\chi_{\max }$ - maksimalna vrijednost, $\bar{x}$ - aritmetička sredina, $\sigma^{2}$ - varijanca, $S_{\bar{x}}-$ standardna pogreška, $\Delta \bar{x}-$ postotno odstupanje aritmetičkih sredina

U tablici 2 prikazani su rezultati Shapiro-Wilkova testa za distribuciju razlika između parova u zadatku FILM. Zaključuje se da nema dovoljno dokaza da distribucija populacije odstupa znatno od normalne razdiobe. Stoga se upotrebljava parametrijski t-test za velike zavisne uzorke čiji su rezultati vidljivi u tablici 3. Kao što je i očekivano, dobivena je statistički značajna razlika u brzini govora za prvi zadatak (FILM).

Tablica 2: Shapiro-Wilkov test normalnosti za zadatak FILM

\begin{tabular}{|c|c|}
\hline FILM & SHAPIRO-WILK \\
\hline$W$ & 0,9820 \\
\hline$p$ & $\mathbf{0 , 1 8 5 8}$ \\
\hline
\end{tabular}

$W$ - Shapiro-Wilkova testovna veličina, $p$ - vjerojatnost dobivanja istih ili ekstremnijih vrijednosti testovne veličine od dobivene vrijednosti, kada je populacija normalno distribuirana

Tablica 3: $t$-test za velike zavisne uzorke za zadatak FILM

\begin{tabular}{|c|c|c|c|}
\hline \multirow{2}{*}{ FILM } & \multicolumn{3}{|c|}{ t-TEST ZA VELIKE ZAVISNE UZORKE } \\
\cline { 2 - 4 } & $t$ & $d f$ & $p$ \\
\cline { 2 - 4 } & 13,94 & 100 & $<0,0001$ \\
\hline
\end{tabular}

$t$ - testovna veličina, $d f$ - broj stupnjeva slobode, $p$ - vjerojatnost dobivanja istih ili ekstremnijih vrijednosti testovne veličine od dobivene vrijednosti, kada je nul-hipoteza točna 
Razlika od više od $22 \%$ u brzini govora između stranoga i materinskoga jezika u prvom zadatku posljedica je prirode samog zadatka. Kormos (2006) i Skehan (2009) pretpostavljaju da konceptualno zahtjevniji zadatci, kao što je u ovom slučaju naracija, zahtijevaju više pažnje u fazi konceptualizacije i nameću znatno opterećenje u radnoj memoriji u različitim fazama proizvodnje govora. Zato govornici koji uporabu stranog jezika još nisu automatizirali češće govore sporije da bi imali više vremena za oblikovanje misli i uspješno jezično kodiranje na svim razinama govorne proizvodnje.

U tablici 4 prikazane su pojedine uzoračke vrijednosti i izračunate veličine za brzinu govora u oba jezika u zadatku SOBA1. Može se primijetiti, za razliku od prethodnog zadatka, da su dobivene vrlo slične vrijednosti za brzine govora u J1 i J2 u ovome zadatku, odnosno da se njihove aritmetičke sredine razlikuju za manje od tri riječi u minuti ili ispod 2,5 \%. Taj iznos nije u skladu s rezultatima dobivenima u dosadašnjoj literaturi.

Tablica 4: Uzoračke vrijednosti i parametri brzine govora za zadatak SOBA1

\begin{tabular}{|c|c|c|}
\hline SOBA1 & Materinski jezik & Strani jezik \\
\hline $\boldsymbol{x}_{\min }$ & 68,108 & 55,365 \\
\hline $\mathbf{M e}$ & 117,757 & 107,865 \\
\hline $\boldsymbol{x}_{\max }$ & 194,521 & 231,148 \\
\hline $\bar{x}$ & $\mathbf{1 1 7 , 6 3 9}$ & $\mathbf{1 1 4 , 7 1 7}$ \\
\hline$\sigma^{2}$ & 523,632 & 1159,811 \\
\hline$S_{\bar{x}}$ & 2,277 & 3,389 \\
\hline$\Delta \bar{x}$ & \multicolumn{2}{|c|}{$-\mathbf{2 , 4 8 4} \%$} \\
\hline
\end{tabular}

$\chi_{\min }$ - minimalna vrijednost, $M e$ - medijan, $\chi_{\max }$ - maksimalna vrijednost, $\bar{\chi}$ - aritmetička sredina, $\sigma^{2}-$ varijanca, $S_{\bar{x}}-$ standardna pogreška, $\Delta \bar{x}$ - postotno odstupanje aritmetičkih sredina

U tablici 5 predstavljeni su rezultati Shapiro-Wilkova testa za zadatak SOBA1. Ispunjen je preduvjet uporabe parametrijskog t-testa za zavisne uzorke. U tablici 6 vidljivi su rezultati njegove primjene, pri čemu nije dobivena statistički značajna razlika između brzina govora u J1 i J2 u ovome zadatku te nije potvrđena postavljena hipoteza. 
Tablica 5: Shapiro-Wilkov test normalnosti za zadatak SOBA1

\begin{tabular}{|c|c|}
\hline SOBA1 & SHAPIRO-WILK \\
\hline$W$ & 0,9811 \\
\hline$p$ & $\mathbf{0 , 1 5 7 9}$ \\
\hline
\end{tabular}

W - Shapiro-Wilkova testovna veličina, $p$ - vjerojatnost dobivanja istih ili ekstremnijih vrijednosti testovne veličine od dobivene vrijednosti, kada je populacija normalno distribuirana

Tablica 6: $t$-test za velike zavisne uzorke za zadatak SOBA1

\begin{tabular}{|c|c|c|c|}
\hline \multirow{2}{*}{ SOBA1 } & \multicolumn{3}{|c|}{ t-TEST ZA VELIKE ZAVISNE UZORKE } \\
\cline { 2 - 4 } & $t$ & $d f$ & $p$ \\
\cline { 2 - 4 } & 0,9781 & 100 & 0,3304 \\
\hline
\end{tabular}

$t$ - testovna veličina, $d f$ - broj stupnjeva slobode, $p$ - vjerojatnost dobivanja istih ili ekstremnijih vrijednosti testovne veličine od dobivene vrijednosti, kada je nul-hipoteza točna

Nepostojanje značajnih razlika u brzini govora u materinskome i stranome jeziku u zadatku SOBA1 može se objasniti time što je riječ o vrlo strukturiranu zadatku koji smanjuje zahtjeve za procesiranjem na razini konceptualizacije te više vremena preostaje za fazu formulacije i artikulacije. Strukturiran govorni zadatak uključuje linearni vremenski slijed, konvencionalnu radnju s početkom, središnjim dijelom i završetkom te određen stupanj familijarnosti, odnosno govorniku bi sadržaj radnje trebao biti donekle poznat otprije. Strukturiranost zadatka umanjuje pritisak zbog procesiranja na razini konceptualizacije, odnosno jasna makrostruktura posljedica je logičnih odnosa između različitih elemenata u priči, a temelji se na relativno poznatu sadržaju. S druge strane, nestrukturirani zadatci koji zahtijevaju manipulaciju novom informacijom ili integriranje dviju radnji u naraciji povezani su s većim stupnjem kompleksnosti (Tavakoli i Skehan 2005). Govornik zapravo ponavlja i prevodi poznati zadatak, odnosno može se pretpostaviti postojanje jakih asocijativnih veza između J1 i J2. Wolter (2001) je proučavajući strukturu mentalnog leksikona zaključio da su J2 leksemi u mentalnome leksikonu organizirani centralno ili periferno te da stupanj poznavanja neke riječi uvjetuje mjesto koje će određena leksička jedinica zauzeti. Posljedično, vrlo poznate riječi smještene su u blizini jezgre leksikona, dok su manje poznate riječi bliže perifernom dijelu leksikona. Vrlo učestale riječi u ovome zadatku (primje- 
rice stol, stolica, ormar, lijevo, desno i sl.) zahtijevaju manji stupanj aktivacije u leksičkom odabiru, poglavito ako su već bile predstavljene na materinskome jeziku. Prethodno izvođenje govornog zadatka na materinskome jeziku olakšalo je izvršavanje istog zadatka na engleskome jeziku. Prema Lambertu i sur. (2016) ponavljanje zadataka ima velik utjecaj na fazu konceptualizacije. U ponovljenu zadatku makrostrukturni konceptualni plan već će biti dostupan, što će zauzvrat pomoći u fazi formulacije jer se umanjuje pritisak u procesiranju govora. U slučaju zahtjevnijih konceptualnih planova govornik vjerojatno neće potpuno upamtiti sadržaj, ali će poznavanje zadatka imati pozitivan učinak na ponavljanje izvedbe. Posljedično, ponavljanje zadataka može ojačati veze koje se uspostavljaju između dviju razina, konceptualizacije i formulacije. Wang (2014), na primjer, ističe da ne samo faza formulacije nego i faza artikulacije imaju bitne koristi od prethodne izvedbe. Stoga, tijekom ponavljanja zadatka govornici se mogu osloniti na prethodno oblikovan konceptualni plan. Isti zaključak ne vrijedi u potpunosti za naraciju, odnosno prvi zadatak, zato što konceptualno zahtjevniji zadatci iziskuju više pažnje u fazi konceptualizacije i nameću znatno opterećenje u radnoj memoriji.

Pojedine komponente u proizvodnji govora, ponajprije konceptualizacija i nadgledanje, pripadaju kontroliranom procesiranju. Ako se umanji teret procesiranja na tim razinama, govornik će dobiti dodatno vrijeme za kontrolirano procesiranje na drugim razinama, odnosno na razinama formulacije i artikulacije, što se očituje i u većoj brzini govora na materinskome jeziku. De Bot (2002), pozivajući se na Leveltov model proizvodnje govora, smatra da, kada je riječ o konceptualizaciji, makroplaniranje nije uvjetovano određenim jezikom te se tek na razini mikroplaniranja stvara predverbalna poruka koja određuje na kojem će se jeziku kodirati poruka.

$S$ obzirom na to da je zadatak SOBA2 ponovljena varijanta zadatka SOBA1, nije neočekivano da je dobivena slična postotna razlika u brzini govora između J1 i J2 kao u zadatku SOBA1, tablica 7. Kao i u prethodnim zadatcima, ispunjen je preduvjet uporabe t-testa za zavisne uzorke, tablica 8 , te je on i proveden, tablica 9. Iz posljednje je tablice vidljivo da, kao i u zadatku SOBA1, nije dobivena statistički značajna razlika između brzine govora u J1 i J2 u ovom zadatku. Posljedično, zaključci vezani uz zadatak SOBA1 vrijede i za zadatak SOBA2. 
Tablica 7: Uzoračke vrijednosti i parametri brzine govora za zadatak SOBA2

\begin{tabular}{|c|c|c|}
\hline SOBA2 & Materinski jezik & Strani jezik \\
\hline $\boldsymbol{x}_{\min }$ & 67,308 & 72,941 \\
\hline $\boldsymbol{M} \boldsymbol{e}$ & 129,412 & 132,719 \\
\hline $\boldsymbol{x}_{\max }$ & 219,178 & 241,148 \\
\hline $\bar{x}$ & $\mathbf{1 2 9 , 4 0 7}$ & $\mathbf{1 3 4 , 0 3 7}$ \\
\hline$\sigma^{2}$ & 620,608 & 940,588 \\
\hline$S_{\bar{x}}$ & 2,479 & 3,052 \\
\hline$\Delta \bar{x}$ & \multicolumn{2}{|c|}{$3, \mathbf{5 7 8} \%$} \\
\hline
\end{tabular}

$x_{\min }$ - minimalna vrijednost, $M e$ - medijan, $x_{\max }$ - maksimalna vrijednost, $\bar{\chi}-$ aritmetička sredina, $\sigma^{2}-$ varijanca, $S_{\bar{x}}-$ standardna pogreška, $\Delta \bar{x}-$ postotno odstupanje aritmetičkih sredina

Tablica 8: Shapiro-Wilkov test normalnosti za zadatak SOBA2

\begin{tabular}{|c|c|}
\hline SOBA2 & SHAPIRO-WILK \\
\hline$W$ & 0,9910 \\
\hline$p$ & $\mathbf{0 , 7 3 8 4}$ \\
\hline
\end{tabular}

$W$ - Shapiro-Wilkova testovna veličina, $p$ - vjerojatnost dobivanja istih ili ekstremnijih vrijednosti testovne veličine od dobivene vrijednosti, kada je populacija normalno distribuirana

Tablica 9: $t$-test za velike zavisne uzorke za zadatak SOBA2

\begin{tabular}{|c|c|c|c|}
\hline \multirow{2}{*}{ SOBA2 } & \multicolumn{3}{|c|}{ t-TEST ZA VELIKE ZAVISNE UZORKE } \\
\cline { 2 - 4 } & $\boldsymbol{t}$ & $d f$ & $p$ \\
\cline { 2 - 4 } & 1,489 & 100 & $\mathbf{0 , 1 3 9 5}$ \\
\hline
\end{tabular}

$t$ - testovna veličina, $d f$ - broj stupnjeva slobode, $p$ - vjerojatnost dobivanja istih ili ekstremnijih vrijednosti testovne veličine od dobivene vrijednosti, kada je nul-hipoteza točna

Iz tablice 10, koja pripada četvrtom zadatku IZORE, mogu se primijetiti niske vrijednosti aritmetičkih sredina brzine govora u materinskome i u stranome jeziku, a koje se međusobno razlikuju za gotovo $7 \%$. Roberts $i$ Kirsner (2000) zaključuju da brzina govora u stranome jeziku opada prije uvođenja nove teme, što je slučaj u zadatku IZORE gdje je svaka rečenica nova tema, a povećava se nakon što je nova tema uvedena. Navedeni autori 
potvrđuju postojanje jake i dosljedne povezanosti između uvođenja nove teme i fluentnosti, odnosno fluentnost se bitno smanjuje uvođenjem nove teme. Razloge nalaze u ograničenu kapacitetu kognitivnih resursa. Količina raspoloživih resursa uvjetuje učinkovitost funkcioniranja određene razine u proizvodnji govora. Makroplaniranje umanjuje raspoloživost kognitivnih resursa za ostale faze proizvodnje govora kao što su formulacija, artikulacija ili nadgledanje govora. Makroplaniranje se odnosi na sustav koji generira semantičko-konceptualni okvir koji pruža osnovu za postizanje komunikacijskog cilja u obliku teme diskursa (Greene i Cappella 1986; Levelt 1989).

Greene i sur. (1993) potvrđuju da će kompleksniji zadatci iziskivati više vremena za makroplaniranje. Također, ako diskurs zahtijeva uvođenje novih elemenata, zahtjevi se na razini makroplaniranja povećavaju, a poznato je da je kapacitet radne memorije ograničen. $S$ druge strane, ako je sadržaj poznat otprije ili se ponavlja, makroplaniranje će mnogo manje utjecati na radnu memoriju. Promjenom teme stvara se nov komunikacijski okvir kojim će se izraziti komunikacijska namjera. Govor će postati fluentan kad završi makroplaniranje i kada se oslobode resursi potrebni za ostale faze govorne proizvodnje. Kovač (2016) u istraživanju brzine govora u stranome jeziku potvrđuje prethodni zaključak.

Nova spoznaja dobivena u ovome radu jest da i u materinskome jeziku brzina govora znatno opada pri uvođenju nove teme jer je dobivena aritmetička sredina brzine govora u J1 ispod 79 riječi u minuti, tablica 10 (što je znatno ispod donje granice uobičajene brzine govora u materinskome jeziku od 120 riječi u minuti u dosadašnjoj literaturi). Naime, najmanja brzina govora zabilježena je u ovome zadatku u kojemu je potrebno više vremena za planiranje i oblikovanje sadržajno nepovezanih izričaja, osobito kada je riječ o manje učestalim leksemima za koje je potrebno dodatno vrijeme za pronalaženje u mentalnom leksikonu.

Rezultati Shapiro-Wilkova testa, tablica 11, pokazuju potrebu korištenjem Wilcoxonovim testom za uparene uzorke. Iako su brzine govora jako niske i u materinskome i u stranome jeziku, ipak postoji statistički značajna razlika između njih, tablica 12 . Zaključci koji se odnose na zadatke SOBA1 i SOBA2 ne mogu se primijeniti na taj zadatak upravo zato što nije riječ o strukturiranu zadatku. Zbog ograničena kapaciteta radne memorije i nepostojanja sadržajne povezanosti između pojedinih izričaja u zadatku, govornik najčešće ne prevodi prethodno odrađeni zadatak, nego oblikuje izričaj pod pritiskom vremenskog ograničenja, što rezultira mnogo sporijom brzinom govora u stranome jeziku. 
Tablica 10: Uzoračke vrijednosti i parametri brzine govora za zadatak IZORE

\begin{tabular}{|c|c|c|}
\hline IZORE & Materinski jezik & Strani jezik \\
\hline $\boldsymbol{x}_{\min }$ & 39,813 & 31,510 \\
\hline $\boldsymbol{M} \boldsymbol{e}$ & 76,125 & 71,555 \\
\hline $\boldsymbol{x}_{\max }$ & 152,727 & 123,328 \\
\hline$\overline{\boldsymbol{x}}$ & $\mathbf{7 8 , 4 6 6}$ & $\mathbf{7 3 , 0 0 2}$ \\
\hline$\sigma^{2}$ & 420,496 & 364,267 \\
\hline$S_{\bar{x}}$ & 2,040 & 1,899 \\
\hline$\Delta \bar{x}$ & \multicolumn{2}{|c|}{$-\mathbf{6 , 9 6 4 \%}$} \\
\hline
\end{tabular}

$\chi_{\min }$ - minimalna vrijednost, $M e$ - medijan, $\chi_{\max }$ - maksimalna vrijednost, $\bar{x}$ - aritmetička sredina, $\sigma^{2}-$ varijanca, $S_{\bar{x}}-$ standardna pogreška, $\Delta \bar{x}-$ postotno odstupanje aritmetičkih sredina

Tablica 11: Shapiro-Wilkov test normalnosti za zadatak IZORE

\begin{tabular}{|c|c|}
\hline IZORE & SHAPIRO-WILK \\
\hline$W$ & 0,9693 \\
\hline$p$ & $\mathbf{0 , 0 1 8 5}$ \\
\hline
\end{tabular}

$W$ - Shapiro-Wilkova testovna veličina, $p$ - vjerojatnost dobivanja istih ili ekstremnijih vrijednosti testovne veličine od dobivene vrijednosti, kada je populacija normalno distribuirana

Tablica 12: Wilcoxonov test za uparene uzorke za zadatak IZORE

\begin{tabular}{|c|c|c|c|c|}
\hline \multirow{2}{*}{ IZORE } & \multicolumn{4}{|c|}{ WILCOXONOV TEST ZA UPARENE UZORKE } \\
\cline { 2 - 5 } & $\begin{array}{c}\text { Suma pozitivnih } \\
\text { rangova }\end{array}$ & $\begin{array}{c}\text { Suma negativnih } \\
\text { rangova }\end{array}$ & $\begin{array}{c}\text { Suma } \\
\text { rangova }\end{array}$ & $p$ \\
\cline { 2 - 5 } & 3456 & -1695 & 1761 & $\mathbf{0 , 0 0 2 9}$ \\
\hline
\end{tabular}

$p$ - vjerojatnost dobivanja istih ili ekstremnijih vrijednosti testovne veličine od dobivene vrijednosti, kada je nul-hipoteza točna

Brzina govora i njihova razlika za posljednji zadatak STRIP prikazane su u tablici 13. S obzirom na to da razdioba razlika između parova u tom zadatku statistički značajno odstupa od normalne distribucije, tablica 14, potrebno je rabiti Wilcoxonov test za uparene uzorke. 
Iako se aritmetičke sredine uzoraka razlikuju za gotovo $5,5 \%$, nije dobivena statistički značajna razlika u brzinama govora između J1 i J2, tablica 15.

Nepostignuta statistički značajna razlika u brzini govora u zadatku oblikovanja kratke priče na temelju slikovnih prikaza može se objasniti prirodom tog zadatka. Riječ je o naraciji kraćeg trajanja, čiji je sadržaj govornik prethodno oblikovao u hrvatskome jeziku i pohranio u radnoj memoriji te ga je najvjerojatnije prevodio izvođenjem na engleskom jeziku. Upoznatost sa sadržajem naracije umanjuje procesne zahtjeve na razini konceptualizacije. S obzirom na to da su J1 leksemi predstavljeni prije, povećava se stupanj aktivacije J2 leksema.

Tablica 13: Uzoračke vrijednosti i parametri brzine govora za zadatak STRIP

\begin{tabular}{|c|c|c|}
\hline STRIP & Materinski jezik & Strani jezik \\
\hline$x_{\min }$ & 25,067 & 39,574 \\
\hline$M e$ & 105,405 & 98,438 \\
\hline$x_{\max }$ & 266,250 & 222,615 \\
\hline $\bar{x}$ & $\mathbf{1 0 8 , 9 8 8}$ & $\mathbf{1 0 3 , 0 1 9}$ \\
\hline$\sigma^{2}$ & 1170,050 & 883,695 \\
\hline$S_{\bar{x}}$ & 3,404 & 2,958 \\
\hline$\Delta \bar{x}$ & \multicolumn{2}{|c|}{$-\mathbf{5 , 4 7 7 \%}$} \\
\hline
\end{tabular}

$\chi_{\min }$ - minimalna vrijednost, $M e$ - medijan, $\chi_{\max }$ - maksimalna vrijednost, $\bar{x}-$ aritmetička sredina, $\sigma^{2}-$ varijanca, $S_{\bar{x}}-$ standardna pogreška, $\Delta \bar{x}-$ postotno odstupanje aritmetičkih sredina

Tablica 14: Shapiro-Wilkov test normalnosti za zadatak STRIP

\begin{tabular}{|c|c|}
\hline STRIP & SHAPIRO-WILK \\
\hline$W$ & 0,9148 \\
\hline$p$ & $<\mathbf{0 , 0 0 0 1}$ \\
\hline
\end{tabular}

$W$ - Shapiro-Wilkova testovna veličina, $p$ - vjerojatnost dobivanja istih ili ekstremnijih vrijednosti testovne veličine od dobivene vrijednosti, kada je populacija normalno distribuirana 
Tablica 15: Wilcoxonov test za uparene uzorke za zadatak STRIP

\begin{tabular}{|c|c|c|c|c|}
\hline \multirow{3}{*}{ STRIP } & \multicolumn{4}{|c|}{ WILCOXONOV TEST ZA UPARENE UZORKE } \\
\cline { 2 - 5 } & $\begin{array}{c}\text { Suma pozitivnih } \\
\text { rangova }\end{array}$ & $\begin{array}{c}\text { Suma negativnih } \\
\text { rangova }\end{array}$ & $\begin{array}{c}\text { Suma } \\
\text { rangova }\end{array}$ & $p$ \\
\cline { 2 - 5 } & 2933 & -2218 & 715 & $\mathbf{0 , 2 2 6 5}$ \\
\hline
\end{tabular}

$p$ - vjerojatnost dobivanja istih ili ekstremnijih vrijednosti testovne veličine od dobivene vrijednosti, kada je nul-hipoteza točna

\section{Zaključak}

Cilj je istraživanja bio utvrditi razlike u brzini govora između materinskoga (hrvatskog) i stranoga (engleskog) jezika za svaki od pet govornih zadataka radi dobivanja novih spoznaja o utjecaju tipa zadatka na razlike u brzini govora. Postavljena hipoteza, prema kojoj će u materinskome jeziku biti zabilježena statistički značajno veća brzina govora u svakom zadatku u odnosu na brzinu govora u odgovarajućim zadatcima na stranome jeziku, potvrđena je samo za određene tipove zadataka. Pretpostavilo se da bi zbog neautomatizirane uporabe stranoga jezika, nedovoljna znanja gramatičkih pravila i leksičkih jedinica govornici trebali znatno sporije govoriti na stranome jeziku u svakom zadatku.

Znanstveni doprinos ovog istraživanja očituje se u novim spoznajama povezanima s ovisnošću brzine govora o tipu govornog zadatka i prethodnom izvršavanju istog zadatka na materinskome jeziku. Kao što je i očekivano, dobivena je statistički značajna razlika u brzini govora za prvi zadatak koji je uključivao prepričavanje radnje filma. Prepričavanje radnje je konceptualno zahtjevan zadatak i zahtijeva više pažnje u fazi konceptualizacije te nameće znatno opterećenje u radnoj memoriji u različitim fazama proizvodnje govora. Govornici koji uporabu stranog jezika još nisu automatizirali češće govore sporije da bi imali više vremena za oblikovanje misli i uspješno jezično kodiranje na svim razinama govorne proizvodnje. $S$ druge strane, nisu dobivene značajne razlike $u$ brzini govora $u$ materinskome i stranome jeziku u zadatcima SOBA1 i SOBA2, što se može objasniti činjenicom da su ispitanici isti zadatak napravili najprije na materinskome, a potom na engleskome jeziku. Za razliku od prvog zadatka ovdje je riječ o vrlo strukturiranim zadatcima koji umanjuju zahtjeve za procesiranjem na razini konceptualizacije te više vremena preostaje za fazu formulacije i artikulacije. Govornik ponavlja i prevodi poznat zadatak, od- 
nosno može se pretpostaviti postojanje jakih asocijativnih veza između J1 i J2. Također, u tim gotovo identičnim zadatcima pojavljuju se vrlo učestale riječi koje zahtijevaju manji stupanj aktivacije leksičkim odabirom, osobito ako su već bile upotrijebljene na materinskome jeziku i pohranjene u radnoj memoriji.

Nova spoznaja dobivena u ovome radu odnosi se i na uvođenje nove teme, to jest $\mathrm{u}$ materinskome je jeziku brzina govora znatno ispod donje granice uobičajene brzine govora u materinskome jeziku u dosadašnjoj literaturi. Najmanja brzina govora zabilježena je u ovome nestrukturiranom zadatku u kojem makroplaniranje umanjuje raspoloživost kognitivnih resursa za ostale faze proizvodnje govora kao što su formulacija, artikulacija ili nadgledanje govora.

Nepostizanje statistički značajnih razlika u brzini govora u petom zadatku oblikovanja kratke priče na temelju slikovnih prikaza može se objasniti prirodom zadatka. Riječ je o naraciji kraćeg trajanja, a s obzirom na to da je prethodno već oblikovan semantičko-konceptualni okvir, govorniku je umanjen pritisak na razini konceptualizacije.

Buduće istraživanje razlika u brzini govora između hrvatskoga i engleskoga jezika, na uzorku studenata koji uče engleski jezik, trebalo bi obuhvatiti mjerenje brzine govora u slogovima po jedinici vremena da bi se uklonile potencijalne razlike u trajanjima prosječne riječi u slogovima, odnosno dobili precizniji rezultati. Rezultati predstavljeni u ovome radu mogu naći praktičnu primjenu u nastavi stranih jezika. Brzina govora smatra se jednim od najboljih parametara za procjenu govornikove fluentnosti u stranome jeziku. Stoga je od velike važnosti uporaba različitih tipova govornih zadataka u nastavi (poznato prema nepoznatom, strukturirano prema nestrukturiranom, ponavljanje prethodno odrađenog zadataka) kojima se potiče opća fluentnost kao vitalni aspekt uspješne komunikacije.

\section{Literatura}

Airey, John (2010) „The ability of students to explain science concepts in two languages", Hermes - Journal of Language and Communication Studies, 45, 35-49.

Anderson-Hsieh, Janet, Kenneth Koehler (1988) „The effect of foreign accent and speaking rate on native speaker comprehension", Language Learning, 38, 561-613. 
Baese-Berk Melissa M., Tuuli H. Morrill (2015) „Speaking rate consistency in native and non-native speakers of English", Journal of the Acoustical Society of America, 138, 223-228.

Bortfeld, Heather, Silvia D. Leon, Jonathan E. Bloom, Michael F. Shober, Susan E. Bennan (2001) „Dysfluency Rate in Conversation: Effects of Age, Relationship, Topic, Role, and Gender", Language and Speech, 42, 123-147.

Cucchiarini, Catia, Helmer Strik, Lou Boves (2002) „Quantitative assessment of second language learners' fluency: Comparisons between read and spontaneous speech", Journal of the Acoustical Society of America, 111, 2862-2873.

De Bot, Kees (2002) „The psycholinguistics of the output hypothesis”, Language Learning, 46, 529-555.

Götz, Sandra (2013) Fluency in native and nonnative English speech, John Benjamins, Amsterdam.

Greene, John O., Joseph N. Cappella (1986) „Cognition and talk: The relationship of semantic units to temporal patterns of fluency in spontaneous speech", Language and Speech, 29, 141-157.

Greene, John O., Tamara L. McDaniel, Kathryn Buksa, Susan M. Ravizza (1993) „Cognitive processes in the production of multiple goal messages: evidence from the temporal characteristics of speech", Western Journal of Communications, 57, 65-86.

Hincks, Rebecca (2005) „Presenting in English and Swedish”, Proceedings FONETIK 2005, The XVIII ${ }^{\text {th }}$ Swedish Phonetics Conference, ur. Anders Eriksson i Jonas Lindh, Göteborg, 45-48.

Hincks, Rebecca (2010) „Speaking rate and information content in English lingua franca oral presentations”, English for Specific Purposes, 29, 4-18.

Horga, Damir (1988) „Latentna struktura brzine izgovora”, Govor, 5, 2, 129-146.

Horga, Damir, Igor Mukić (2000) „Neki vremenski parametri govora u dnevnicima HTV-a", Govor 27, 2, 105-121.

Horga, Damir, Vesna Požgaj Hadži (2012) „(Dis)fluentnost i proizvodnja govora", Slavistična revija, 60, 4, 621-637.

Kormos, Judit (2006) „Speech production and second language acquisition”, Lawrence Erlbaum Associates, New York, London. 
Kormos, Judit, Mariann Dénes (2004) „Exploring measures and perceptions of fluency in the speech of second language learners", System, 32, 145-164.

Kovač, Mirjana M. (2016) „The Influence of Task Type on Perceived Fluency”, Studies in English Language Teaching, 4, 2, 241-252.

Lambert, Craig, Judit Kormos, Danny Minn (2017) „Task repetition and second language speech processing", Studies in Second Language Acquisition, 39, 1, 167-196.

Levelt, Willem J. M. (1989) Speaking. From Intention to Articulation, MIT Press, Cambridge, MA.

Marslen-Wilson, William (1973) „Linguistic structure and speech shadowing at very short latencies", Nature, 244, 522-523.

Munro, Murray J., Tracey M. Derwing (1995) „Foreign accent, comprehensibility and intelligibility in the speech of second language learners", Language Learning, 45, 73-97.

Munro, Murray J., Tracey M. Derwing (1998) „The effects of speaking rate on listeners evaluations of native and foreign-accented speech", Language Learning, 48, 159-182.

Munro, Murray J., Tracey M. Derwing (2001) „Modeling perceptions of the accentedness and comprehensibility of L2 speech: The role of speaking rate", Studies in Second Language Acquisition, 23, 451468.

Pimsleur, Paul, Charles Hancock, Patricia Furey (1977) „Speech rate and listening comprehension", u: View-points on English as a Second Language, ur. Marina K. Burt, Heidi C. Dulay, Mary B. Finocchiaro, Regents, New York, 27-34.

Požgaj Hadži, Vesna, Damir Horga, Tatjana Balažic Bulc (2012) „Speech fluency: a result of oral language proficiency", Linguistica, 52, 87100.

Richards, Brian (1983) „Type/token ratios: What do they really tell us?”, Journal of Child Language, 14, 2, 201-209.

Rivers, Wilga M. (1981) Teaching foreign language skills, University of Chicago Press, Chicago.

Roberts, Benjamin i Kim Kirsner (2000) „Temporal cycles in speech production", Language and Cognitive Processes, 15, 129-157. 
Skehan, Peter (2009) „Modelling second language performance: integrating complexity, accuracy, fluency, and lexis", Applied Linguistics 30, 4, 510-532.

Škarić, Ivo (1991) „Fonetika hrvatskoga književnog jezika”, u: Povijesni pregled, glasovi i oblici hrvatskoga književnog jezika, ur. Radoslav Katičić, 61-372, Nakladni zavod Globus, Zagreb.

Tavakoli, Parvaneh, Peter Skehan (2005) „Strategic planning, task structure and performance testing”, u: Planning and task performance in a L2, ur. Rod Ellis, John Benjamins Amsterdam, 239-273.

Thogersen, Jacob, John Airey (2011) „Lecturing undergraduate science in Danish and in English: A comparison of speaking rate and rhetorical style”, English for Specific Purposes, 30, 209-221.

Trofimovich, Pavel, Wendi Baker (2006) „Learning second language suprasegmentals: Effect of L2 experience on prosody and fluency characteristics of L2 speech", Studies in Second Language Acquisition, 28, 1, 1-30.

Ullakonoja, Riikka (2009) „Speech rate as an indicator of fluency in the Russian of Finnish learners", The Phonetics Symposium 2008. Tampere Studies in Language, Translation and Culture, Series B, ur. Michael O’Dell i Tommi Nieminen, Tampere, 97-109.

Wang, Zhan (2014) „On-line time pressure manipulations: L2 speaking performance under five types of planning and repetition conditions", $\mathrm{u}$ : Processing perspectives on task performance, ur. Peter Skehan, John Benjamins, Amsterdam, 27-62.

Wolter, Brent (2001) „Comparing the L1 and L2 mental lexicon. A depth of individual word knowledge model”, Studies in Second Language Acquisition, 23, 41-69.

Zuengler, Jane (1988) „Identity markers and L2 pronunciation”, Studies in Second Language Acquisition, 10, 33-49. 


\section{SUMMARY}

Mirjana Matea Kovač

COMPARISON OF SPEECH RATE IN CROATIAN AS A NATIVE LANGUAGE (L1) AND ENGLISH AS A FOREIGN LANGUAGE (L2)

This paper aims at investigating the differences regarding speech rate between the Croatian (L1) and the English language (L2). The selected tasks include descriptions of dynamic entities which require careful planning and a chronological sequence of speech acts in real time, as well as the description of static spatial arrangements and their relations. The speech tasks were first performed in the native language, followed by the performance of the same tasks in the foreign language. A significantly faster speech rate was hypothesized in the foreign language condition for each investigated speech task due to the unautomated nature of L2 speech production mechanisms. The obtained results point to the conclusion that the speech rate is significantly slower in L2 in narrative tasks due to the conceptual complexity of the task. However, no significant differences in the speech rate were found between the two languages in the case of highly structured tasks with shorter duration, or in the case of repeated tasks. Due to the fact that the tasks have already been performed in the native language, the processing demands on the level of conceptualization decrease, freeing up the attentional resources, which, in turn, assist the formulation and articulation stage by reducing the processing pressure. Also, the fact that no significant differences were found might be explained by the existence of strong associative links between L1 and L2, as well as by the occurrence of highly frequent words which can be easily retrieved from the mental lexicon, especially if they have previously been activated in the native language. Introduction of new topics, on the other hand, implies higher cognitive demands in the conceptualization stage, resulting in a slower speech rate in both languages.

Keywords: speech rate; speech production; fluency; mental lexicon 
